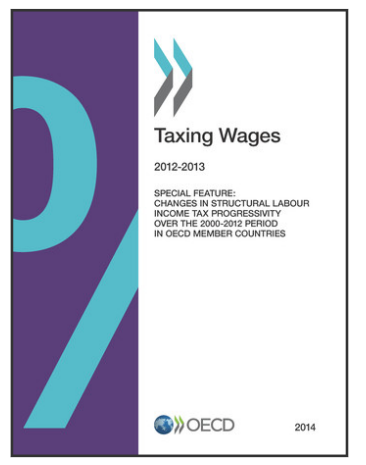

\title{
From:
}

Taxing Wages 2015

Access the complete publication at: http:// dx.doi.org/10.1787/tax_wages-2015-en

\section{Special Feature: Modelling the tax burden on labour income in Brazil, China, India, Indonesia and South Africa}


This work is published on the responsibility of the Secretary-General of the OECD. The opinions expressed and arguments employed herein do not necessarily reflect the official views of the OECD or of the governments of its member countries or those of the European Union.

This document and any map included herein are without prejudice to the status of or sovereignty over any territory, to the delimitation of international frontiers and boundaries and to the name of any territory, city or area. 


\section{Special Feature: Modelling the tax burden on labour income in Brazil, China, India, Indonesia and South Africa}

This Special Feature examines the taxation of labour income in five major non-OECD economies: Brazil, China, India, Indonesia and South Africa. It sets out the key features of the taxation of labour income in each of the five countries in 2013 and then uses this information together with corresponding details for earlier years to model changes to the tax burden between 2010 and 2013 in each case. The analysis follows the pattern of the main Taxing Wages Report. It calculates the tax wedge and the net personal average tax rate for a single worker on average earnings. These results are then compared with those for a single earner married couple with two children and then extended to cover all eight of the model family types.

The statistical data for Israel are supplied by and under the responsibility of the relevant Israeli authorities. The use of such data by the OECD is without prejudice to the status of the Golan Heights, East Jerusalem and Israeli settlements in the West Bank under the terms of international law. 


\section{INDIA 2013}

This chapter includes data on the income taxes paid by workers, their social security contributions, the family benefits they receive in the form of cash transfers as well as the social security contributions and payroll taxes paid by their employers. Results reported include the marginal and average tax burden for eight different family types.

Methodological information is available for personal income tax systems, compulsory social security contributions to schemes operated within the government sector, universal cash transfers as well as recent changes in the tax/ benefit system. The methodology also includes the parameter values and tax equations underlying the data. 


\section{India (including social security contributions) 2013}

The tax/benefit position of single persons

Wage level (per cent of AW)

Number of children

1. Gross wage earnings

2. Standard tax allowances

Basic allowance

$\begin{array}{rrrr}67 & 100 & 167 & 67 \\ \text { none } & \text { none } & \text { none } & 2 \\ 53545 & 79917 & 133462 & 53545 \\ 7362 & 1399 & 2336 & 7362\end{array}$

Married or head of family

362

Dependent children

Deduction for social security contributions and income taxes

Work-related expenses

Other

3. Tax credits or cash transfers included in taxable income

4. Central government taxable income $(1-2+3)$

Total

7362
0
46182

1399

2336

7362

. Central government income tax liability (exclusive of tax credits)

(1)

78519131126

46182

6. Tax credits

Basic credit

Married or head of family

Children

Other

7. Central government income tax finally paid (5-6)

8. State and local taxes

9. Employees' compulsory social security contributions Gross earnings

Taxable income

10. Total payments to general government $(7+8+9)$

11. Cash transfers from general government

For head of family

For two children

12. Take-home pay $(1-10+11)$

13. Employer's compulsory social security contributions

14. Average rates

Income tax

Employees' social security contributions

Total payments less cash transfers

Total tax wedge including employer's social security contributions

Total

$$
0
$$

(20)

0

$\begin{array}{llll}0 & 0 & 0 & 0\end{array}$

$\begin{array}{llll}0 & 0 & 0 & 0\end{array}$

$\begin{array}{llll}0 & 0 & 0 & 0 \\ 0 & 0 & 0 & 0\end{array}$

$362 \quad 1399 \quad 2336 \quad 7362$

Total $\quad 7362 \quad 1399 \quad 2336 \quad 7362$

$\begin{array}{llll}7362 & 1399 & 2336 & 7362\end{array}$

Marginal rates

Total payments less cash transfers: Principal earner

Total payments less cash transfers: Spouse

Total tax wedge: Principal earner

Total tax wedge: Spouse

$\begin{array}{rrrrr} & 0 & 0 & 0 & 0 \\ \text { Total } & 0 & 0 & 0 & 0 \\ 46182 & 78519 & 131126 & 46182 \\ 8969 & 3796 & 6339 & 8969 \\ & & & \\ 0.0 \% & 0.0 \% & 0.0 \% & 0.0 \% \\ 13.8 \% & 1.8 \% & 1.8 \% & 13.8 \% \\ 13.8 \% & 1.8 \% & 1.8 \% & 13.8 \% \\ 26.1 \% & 6.2 \% & 6.2 \% & 26.1 \% \\ & & & \\ 13.7 \% & 1.8 \% & 1.7 \% & 13.7 \% \\ \text { n.a. } & \text { n.a. } & \text { n.a. } & \text { n.a. } \\ 26.1 \% & 6.2 \% & 6.2 \% & 26.1 \% \\ \text { n.a. } & \text { n.a. } & \text { n.a. } & \text { n.a. }\end{array}$


India (including social security contributions) 2013

\section{The tax/benefit position of married couples}

Wage level (per cent of AW)

Number of children

1. Gross wage earnings

$\begin{array}{rrrr}100-0 & 100-33 & 100-67 & 100-33 \\ 2 & 2 & 2 & \text { none }\end{array}$

$79917 \quad 106290 \quad 133462 \quad 106290$

Standard tax allowances

Basic allowance

$1399 \quad 5025 \quad 8761 \quad 5025$

Married or head of family

Dependent children

Deduction for social security contributions and income taxes

Work-related expenses

Other

3. Tax credits or cash transfers included in taxable income

4. Central government taxable income $(1-2+3)$

5. Central government income tax liability (exclusive of tax credits)

6. Tax credits

Basic credit

Married or head of family

Children

Other

7. Central government income tax finally paid (5-6)

8. State and local taxes

9. Employees' compulsory social security contributions

Gross earnings

Taxable income

10. Total payments to general government $(7+8+9)$

11. Cash transfers from general government

For head of family

For two children

12. Take-home pay $(1-10+11)$

13. Employer's compulsory social security contributions

14. Average rates

Income tax

Employees' social security contributions

Total payments less cash transfers

Total tax wedge including employer's social security contributions

15. Marginal rates

Total payments less cash transfers: Principal earner

Total payments less cash transfers: Spouse

Total tax wedge: Principal earner

Total tax wedge: Spouse

\begin{tabular}{|c|c|c|c|c|}
\hline & 0 & 0 & 0 & 0 \\
\hline \multirow[t]{5}{*}{ Total } & 1399 & 5025 & 8761 & 5025 \\
\hline & 0 & 0 & 0 & \\
\hline & 78519 & 101265 & 124701 & 101265 \\
\hline & 0 & 0 & 0 & \\
\hline & 0 & 0 & 0 & \\
\hline \multirow[t]{4}{*}{ Total } & 0 & 0 & 0 & \\
\hline & 0 & 0 & 0 & \\
\hline & 0 & 0 & 0 & \\
\hline & 1399 & 5025 & 8761 & 5025 \\
\hline \multirow[t]{3}{*}{ Total } & 1399 & 5025 & 8761 & 5025 \\
\hline & 1399 & 5025 & 8761 & 5025 \\
\hline & 0 & 0 & 0 & \\
\hline \multirow[t]{11}{*}{ Total } & 0 & 0 & 0 & \\
\hline & 78519 & 101265 & 124701 & 101265 \\
\hline & 3796 & 8213 & 12765 & 8213 \\
\hline & $0.0 \%$ & $0.0 \%$ & $0.0 \%$ & $0.0 \%$ \\
\hline & $1.8 \%$ & $4.7 \%$ & $6.6 \%$ & $4.7 \%$ \\
\hline & $1.8 \%$ & $4.7 \%$ & $6.6 \%$ & $4.7 \%$ \\
\hline & $6.2 \%$ & $11.6 \%$ & $14.7 \%$ & $11.6 \%$ \\
\hline & $1.8 \%$ & $1.7 \%$ & $1.8 \%$ & $1.7 \%$ \\
\hline & $13.8 \%$ & $13.7 \%$ & $13.8 \%$ & $13.7 \%$ \\
\hline & $6.2 \%$ & $6.2 \%$ & $6.2 \%$ & $6.2 \%$ \\
\hline & $26.1 \%$ & $26.1 \%$ & $26.1 \%$ & $26.1 \%$ \\
\hline
\end{tabular}


India (no social security contributions) 2013

The tax/benefit position of single persons

Wage level (per cent of AW)

Number of children

1. Gross wage earnings

2. Standard tax allowances

Basic allowance

$\begin{array}{rrrr}67 & 100 & 167 & 67 \\ \text { none } & \text { none } & \text { none } & 2\end{array}$

$79917 \quad 133462 \quad 53545$

Married or head of family

Dependent children

Deduction for social security contributions and income taxes

Work-related expenses

Other

3. Tax credits or cash transfers included in taxable income

4. Central government taxable income $(1-2+3)$

Total

5. Central government income tax liability (exclusive of tax credits)

53545

0

$0 \quad 0$

6. Tax credits

Basic credit

Married or head of family

Children

Other

7. Central government income tax finally paid (5-6)

8. State and local taxes

9. Employees' compulsory social security contributions

Gross earnings

Taxable income

10. Total payments to general government $(7+8+9)$

0

0

$0 \quad 0 \quad 0$

$0 \quad 0 \quad 0 \quad 0$

11. Cash transfers from general government

For head of family

For two children

12. Take-home pay $(1-10+11)$

13. Employer's compulsory social security contributions

14. Average rates

Income tax

Employees' social security contributions

Total payments less cash transfers

Total tax wedge including employer's social security contributions

$$
0
$$

0

Total

0

Marginal rates

Total payments less cash transfers: Principal earner

Total payments less cash transfers: Spouse

Total tax wedge: Principal earner

Total tax wedge: Spouse

Total 
India (no social security contributions) 2013

\section{The tax/benefit position of married couples}

Wage level (per cent of AW)

Number of children

1. Gross wage earnings

$\begin{array}{rrrr}100-0 & 100-33 & 100-67 & 100-33 \\ 2 & 2 & 2 & \text { none }\end{array}$

$79917 \quad 106290 \quad 133462 \quad 106290$

2. Standard tax allowances

Basic allowance

0

$0 \quad 0 \quad 0$

Married or head of family

Dependent children

Deduction for social security contributions and income taxes

Work-related expenses

Other

3. Tax credits or cash transfers included in taxable income

4. Central government taxable income $(1-2+3)$

5. Central government income tax liability (exclusive of tax credits)

6. Tax credits

Basic credit

Married or head of family

Children

Other

7. Central government income tax finally paid (5-6)

8. State and local taxes

9. Employees' compulsory social security contributions

Gross earnings

Taxable income

10. Total payments to general government $(7+8+9)$

11. Cash transfers from general government

For head of family

For two children

12. Take-home pay $(1-10+11)$

13. Employer's compulsory social security contributions

$\begin{array}{llll}0 & 0 & 0 & 0\end{array}$

Total

$\begin{array}{rrrr}0 & 0 & 0 & 0 \\ 0 & 0 & 0 & 0 \\ 79917 & 106290 & 133462 & 106290\end{array}$

$\begin{array}{llll}106290 & 133462 \quad 106290\end{array}$

4. Average rates

Income tax

Employees' social security contributions

Total payments less cash transfers

Total tax wedge including employer's social security contributions

15. Marginal rates

Total payments less cash transfers: Principal earner

Total

$$
0
$$

$$
0
$$

Total payments less cash transfers: Spouse

Total tax wedge: Principal earner

Total tax wedge: Spouse 
The national currency is the rupee (INR). In 2013, INR 58.60 equalled USD 1. The average worker earned INR $79917^{1}$.

\section{Personal income tax system}

The tax rules relate to the year of assessment 1 April 2013 to 31 March 2014 applicable on income earned during the fiscal year 1 April 2012 to 31 March 2013.

\subsection{Central government income tax}

Resident individuals are subject to tax on their worldwide income, which includes capital gains.

Income is divided into the following heads:

- salaries;

- income from housing property;

- income from a business or profession;

- capital gains; and

- income from other sources.

Different accessibility and deductibility rules apply to each head of income. The resulting net chargeable amounts for each head are aggregated to arrive to a total income. The taxable income on which the applicable tax rates are applied, is then calculated after the deduction of certain allowances (such as for losses and donations).

Taxable salary includes wages, annuities, pensions, perquisites in lieu of or in addition to salary, benefits, voluntary contributions by the employer to a recognized provident fund and advances.

Most benefits in kind are treated as perquisites, but the following benefits provided by the employer to the employee are taxable:

- accommodation: the taxable value is $20 \%$ of the employee's salary for accommodation located in cities with a population of more than 400,000 , and $15 \%$ for other cities;

- automobiles: taxable value is the actual amount incurred by the employer, including the costs of maintenance, operation and remuneration of a chauffeur;

- furniture and fittings: $10 \%$ of the actual costs of the furniture or fittings, or actual amount of rent if the items are leased;

- interest-free/concessional loans: loans exceeding INR 20,000 are deemed to carry the annual rate charged by the State Bank of India;

- health insurance premiums and medical expenses: amounts in excess of INR 15,000 per annum paid by the employer for health insurance premiums or reimbursement of medical expenses; and

- leave travel: leave passages in excess of two journeys in a period of 4 years.

\section{Exempt income:}

\footnotetext{
${ }^{1}$ See section 5.1.
} 
Certain specified types of income received by individuals are exempt, e.g. travel concessions, retrenchment compensation, payment received in lieu of unutilized leave, insurance receipts, pensions and payments from recognized provident/superannuation funds. Some exempted incomes are subject to limitations.

\subsubsection{Tax unit}

Each person is taxed separately.

\subsubsection{Tax allowances and tax credits}

\subsubsection{Standard tax allowances and tax credits}

- Mandatory contributions to social security are deductible.

- Professional or employment tax that is levied by State Governments is deductible.

- There are no standard allowances or deductions and no family tax relief.

1.1.2.2. Main non-standard tax allowances and tax credits

There are two kinds of allowances for children:

- Children Education Allowance: INR 100 per month per child up to a maximum of two children;

- $\quad$ any allowance granted to an employee to meet the hostel expenditure on his child: INR 300 per month per child up to a maximum of two children.

The Childrens' Education and Hostel expenditure allowances are paid by the government to reimburse school tuition fees and expenses up to limits and for a maximum of two children. They are not considered as standard with respect to the Taxing Wages methodology, because they are not available to all taxpayers or wage earners.

In general, a deduction is also allowed for a number of specified contributions subject to limits:

- pension contributions or life insurance payments up to INR 100000 annually;

- medical insurance premiums for the taxpayers and relatives, up to INR 15000 annually;

- medical expenses not covered by insurance, up to INR 40000 annually;

- physically handicapped taxpayers or taxpayers with physically handicapped dependents (up to INR 100 000)

Certain interests on loans used to finance higher education are deductible with no limits. Repayment of mortgage principal and interest are also deductible.

There are no non-standard tax credits.

\subsubsection{Tax schedule}

The tax rates for individuals aged under 65 for the 2013/14 assessment year (i.e. fiscal year 1 April 2012 to 31 March 2013) are as follows: 


\begin{tabular}{|l|l|}
\hline \multicolumn{1}{|c|}{ Annual taxable income (INR) } & \multicolumn{1}{c|}{ Rate (\%) } \\
\hline Up to 200000 & 0 \\
\hline $200000-500000$ & 10 \\
\hline $500000-1000000$ & 20 \\
\hline Over 1000000 & 30 \\
\hline
\end{tabular}

An Education Cess is levied at the rate of $2 \%$ of the income tax liability. A secondary and higher Education Cess of $1 \%$ is also levied on the income tax liability.

\subsection{State and local taxes}

The professional tax is imposed at the state level by the following states - Karnataka, West Bengal, Andhra Pradesh, Maharashtra, Tamilnadu, Gujarat, and Madhya Pradesh. Business owners, individuals working in private companies, merchants and people carrying out various occupations come under the purview of this tax. Other States do not impose this tax.

The professional or employment tax is eligible as a deduction for the calculation of the central government income tax liability. The amount so paid can be deducted from the taxable salary.

The tax rates and thresholds for 2013 in New Delhi, Maharashtra and West Bengal are as indicated in the tables below. The New Delhi professional tax schedule is implemented in the Taxing Wages model.

\section{Professional Tax schedule in New Delhi}

\begin{tabular}{|l|l|}
\hline \multicolumn{1}{|c|}{ Earnings (INR) } & \multicolumn{1}{|c|}{ Rate (\%) } \\
\hline Up to 110000 & Nil \\
\hline From 110000 to 145000 & Nil \\
\hline From 145000 to 150000 & 10 \\
\hline From 150 000 to 195000 & 20 \\
\hline From 195000 to 250 000 & 20 \\
\hline Over 250 000 & 30 \\
\hline
\end{tabular}

\section{Professional Tax schedule in Maharashtra}

\begin{tabular}{|l|l|}
\hline \multicolumn{1}{|c|}{ Earnings (INR) } & \multicolumn{1}{|c|}{$\begin{array}{c}\text { Tax to be imposed } \\
\text { (INR) }\end{array}$} \\
\hline Up to 2 500 & Nil \\
\hline From 2 500 to 3 500 & 60 \\
\hline From 3 500 to 5 000 & 120 \\
\hline From 5 000 to 10 000 & 175 \\
\hline Over 10 000 & 200 \\
\hline
\end{tabular}


Professional Tax schedule in West Bengal

\begin{tabular}{|l|l|}
\hline \multicolumn{1}{|c|}{ Earnings (INR) } & \multicolumn{1}{|c|}{$\begin{array}{c}\text { Tax to be imposed } \\
\text { (INR) }\end{array}$} \\
\hline Up to 1 500 & Nil \\
\hline From 1 500 to 2 000 & 18 \\
\hline From 2 000 to 3 000 & 25 \\
\hline From 3 000 to 5 000 & 30 \\
\hline From 5 000 to 6 000 & 40 \\
\hline From 6 000 to 7 000 & 45 \\
\hline From 7 000 to 8 000 & 50 \\
\hline From 8 000 to 9 000 & 90 \\
\hline From 9 000 to 15000 & 110 \\
\hline From 15000 to 25000 & 130 \\
\hline From 25000 to 40 000 & 150 \\
\hline Over 40 000 & 200 \\
\hline
\end{tabular}

\section{Compulsory social security contributions to schemes operated within the government sector}

\subsection{Employee contributions}

Both employees and employers are required to contribute to the Employees Provident Fund. Membership is compulsory for employees in establishments employing 20 persons or more.

Employees earning up to INR 6500 per month are required to contribute 12\% (10\% in certain cases) of gross salary to the Employees Provident Fund. Employees earning more than INR 6500 per month are not compelled to join the scheme, but may opt to do so. Voluntary higher contributions are also acceptable at the joint request of the member and the employer.

Employees who are industrial workers are also required to contribute $1.75 \%$ of the gross salary to the Employees State Insurance Corporation for the provision of health insurance. The contribution is capped at a monthly gross salary of INR 15000 per month.

The contributions are deductible for tax purposes.

\subsection{Employer contributions}

Employers are required to contribute $12 \%$ (10\% in certain cases) of gross salary to the Employees Provident Fund.

Employers of industrial workers are also required to contribute $4.75 \%$ of the gross salary to the Employees State Insurance Corporation for the provision of health insurance. The contribution is capped at a monthly gross salary of INR 15000 per month.

\section{Universal cash transfers}

\subsection{Amount for spouse and for dependent children}

None

\section{Main changes in tax/benefit systems since 2012}

None 


\section{Memorandum items}

\subsection{Identification of an $A W$}

The data refer to the annual earnings of average workers.

The average wage value derives from the International Labor Organization statistical database (ILOSTAT). The latest available average wage value is for 2006 and corresponded to a monthly value of INR 3 525.9. The figure is based on ISIC rev 2 and covers only the manufacturing sector, including both men and women. The average wage value has been adjusted using information on the annual inflation rates for India up to 2013 retrieved from the OECD database on Consumer Prices - Annual inflation (http://dotstat.oecd.org//Index.aspx?QueryId=22519).

\subsection{Contributions by employers to private pension funds, health and related schemes}

From 1 May 2009, a New Pension Scheme (NPS) has been extended to all Indian citizens (resident and non-resident) between the ages of 18 and 55 years on a voluntary basis. The NPS is a scheme based on defined contributions by members and matching contributions from employers, and is not applicable to individuals covered by the Provident Fund Act. All central government employees have been under the NPS since 1 January 2004.

The new pension scheme is voluntary for self-employed individuals, private companies and the unorganized sector, and there will be no contribution from the government in respect of individuals who are not government employees.

The minimum contribution is INR 500 per month for a minimum of 4 years of contribution, with no ceiling on the total contribution per year or on the number of years of contributions.

The NPS is divided into 2 types of accounts, i.e.:

- Tier I Account: where savings contributed for retirement are deposited and is a non-withdrawal account (available from 1 May 2009); and

- Tier II Account: a voluntary savings account from which contributions may be withdrawn as per the subscriber's choice (date of availability as yet undetermined).

The subscriber may elect for one of two approaches with regards to the investment of his NPS account, i.e.:

- an active choice whereby the subscriber can choose how his funds should be invested from among three options, i.e. (i) investment in equity instruments (capped at $50 \%$ of total investment); (ii) investment in fixed income instruments other than government securities; and (iii) investment in government securities; and

- an automatic choice whereby the subscriber has no choice as to asset allocation, which will be done based on the age of the subscriber.

Subscribers may exit from the NPS as follows:

- age below 60 years: $80 \%$ of the fund will be used to purchase a life annuity plan from an authorized insurance company, and the balance of $20 \%$ may be withdrawn as a lump sum; 
- age between 60 and 70 years: $40 \%$ of the fund will be used to purchase a life annuity plan from an authorised insurance company, and the balance may be withdrawn as a lump sum or in instalments of a minimum of $10 \%$ per year; and

- age over 70 years: compulsory full withdrawal. 